\title{
EFFECT OF INCORPORATING RICE BRAN OR PARBOILED RICE POLISH WITH OR WITHOUT EXOGENOUS PHYTASE IN THE DIET ON GROWTH OF JINDING DUCKLINGS
}

\section{Nebash Chandra Pal, Syed Mohammad Bulbul, Zannatul Mawa and Muslah Uddin Ahammad*}

Department of Poultry Science, Faculty of Animal Husbandry, Bangladesh Agricultural University, Mymensingh-2202, Bangladesh

*Corresponding author: Muslah Uddin Ahammad; E-mail: ahammad.muslah@gmail.com

\begin{tabular}{|c|c|}
\hline ARTICLE INFO & ABSTRACT \\
\hline Received & A total of 48 straight-run day old ducklings (DOD) of Jinding were fed ad libitum on four (4) \\
\hline 1.2015 & $\begin{array}{l}\text { iso-nitrogenous and iso-caloric diets }(3000 \mathrm{Kcal} \mathrm{ME} / \mathrm{kg} \text { and } 22 \% \mathrm{CP} \text { ) having } 3 \text { replicates } \\
\text { each. The diets were formulated using } 20 \% \text { rice bran (RB) or parboiled rice polish (PRP) }\end{array}$ \\
\hline Accepted & with or without exogenous phytase $(10 \mathrm{~g} / \mathrm{kg})$. Ducklings were fed up to 28 days of age to \\
\hline 09.12 .2015 & $\begin{array}{l}\text { observe the effect of RB and PRP based diet on the growth performance. Feeding of PRP } \\
\text { based diet with enzyme resulted in increased live weight gain and feed efficiency. There was }\end{array}$ \\
\hline Online & no difference in feed intake on both diets $(p>0.05)$. However, the formulating cost of PRP \\
\hline 21.12 .2015 & $\begin{array}{l}\text { based diet was higher than that of RB based diet. Addition of enzyme promoted growth and } \\
\text { feed efficiency but did not affect feed intake significantly during the experimental period and }\end{array}$ \\
\hline Key words & increased feed cost. Therefore, it appeared that the biological performance of PRP based \\
\hline Rice bran & that of RB based diet. However, the feed cost \\
\hline Parboiled rice polish & was less in RB based diet with or without phytase. Therefore, to formulate low cost diet, RB \\
\hline Phytase & for better growth performance PRP can be used in the \\
\hline Growth & diet of ducklings. In conclusion, the findings demonstrated that the PRP based diets with or \\
\hline Jinding duckling & $\begin{array}{l}\text { without phytase was superior to RB based diets with or without phytase in terms of growth } \\
\text { performance, but RB based diet was superior in terms of feed cost. Therefore, it appeared } \\
\text { that increased growth performance cannot be a basis of using RB and PRP. Rather, cost- } \\
\text { effectiveness of feeding ducklings on RB and PRP based diet must be taken into account. }\end{array}$ \\
\hline
\end{tabular}

To cite this article: Pal N C, S M Bulbul, Z Mawa and M U Ahammad, 2015. Effect of incorporating rice bran or parboiled rice polish with or without exogenous phytase in the diet on growth of Jinding ducklings. Res. Agric. Livest. Fish. 2 (3): 445-451.

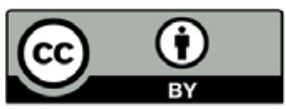

This is an open access article licensed under the terms of the Creative Commons Attribution 4.0 International License

www.agroaid-bd.org/ralf, E-mail: editor.ralf@gmail.com 


\section{INTRODUCTION}

Duck rearing is an integral part of rural poultry husbandry in Bangladesh. It provides with additional income especially for the rural women and acts as an important tool for poverty alleviation. According to the reports by FAO (2009), total duck population in Bangladesh is more than 18 million. Bangladesh is a riverine country. About $16488 \mathrm{~km}^{2}$ of its total area are haors, baors, canals, ponds and low lying water reservoirs (Asian Livestock, 1978). The climatic conditions and innumerable water bodies of Bangladesh are suitable for duck habitation and production. Duck requires no additional care, management and supply of feed. They are hardier, capable to withstand the abuses of harsh climate with minimal management and inadequate nutrition, and are less susceptible to diseases compared with chicken. In addition, they are not competitor of chicken for feed because, they mainly scavenge in low-lying water lodged areas that are not suitable for chicken to scavenge around. It is well known that the indigenous (deshi) ducks can lay more eggs with larger size than the deshi chicken. Thus, ducks, being the most important versatile poultry species, can contribute to the increment in egg and meat production in Bangladesh.

In poultry production, it is well recognized that the feed cost alone accounts for about $65-70 \%$ of the total cost of production (Banerjee, 1992). In poultry farming of Bangladesh, high price and poor quality of most abundantly used feed ingredients are the major prevailing constraints, which may be alleviated through exploration of locally available cheaper potential feedstuffs and by introducing nutritional advanced technology to ensure high bio-availability of nutrients from the diets. In fact, poultry competes directly with human and other livestock for major grains such as wheat and maize, which are usually incorporated at a rate of $50-60 \%$ in the total diet formulated for feeding poultry. However, they are less available as compared to their demand. Therefore, it is imperative to explore the possibilities of using locally available cheaper grains or nutritionally equivalent their by-products to reduce feed cost. RB and PRP are the only by-products of abundantly grown grains, the paddy in Bangladesh. In relevance, when compared with chicken, ducks have been shown to be capable of consuming and utilizing more fibrous diet very efficiently. RB is a by-product of paddy obtained from rice milling processes. It consists of the combined aleurone and pericarp (McDonald, 1987).

In Bangladesh, most of the farmers, who rear ducks traditionally, use RB for the feeding of ducks. Since RB contains more fiber of coarse type, it is not well utilized by physiological process of ducks which ultimately reduces growth performance of ducks. Juliano (1985) reported that RB also contains anti-nutritional factors. RB has higher phytin P content (24 to $46 \mathrm{~g} / \mathrm{kg}$ ) than other cereal brans (Thomson and Weber, 1981; Warren et al., 1990) which is relatively unutilizable to poultry. A heat stable factor pepsin inhibitor, present in both bran and germ was identified as phytin P (Kanaya et al., 1976). However, the duck producers in Bangladesh do not know about the bad effect of using RB as duck feed. In contrast, the other potential by-product of paddy is rice polish (RP), which has been shown to contain only $2.7 \%$ fiber and as much protein and fat as in RB (Morrison, 1957). It has been reported that RP constitutes about $10 \%$ of paddy and is available in large quantities in major paddy growing areas of the world (Houston and Kohler, 1970). It might be used as an alternative to grains and RB in feeding ducks. There are 3 major types of RP namely raw RP, deoiled RP and PRP. The raw RP is not a suitable feed for poultry feeding. It has been shown that PRP is more stable to the oxidative hydrolysis and is less susceptible to the development of free fatty acids to be rapidly oxidized during storage than that of raw RP (Shaheen et al., 1975). Due to application of modern techniques in agriculture, paddy production in the country has increased. During milling in hullers considerable amount of breakage of rice occurs which reduces the quantity of consumable rice of a given quantity of paddy. To withstand the milling pressure, rice kernel has to be hardened by some preprocessing techniques. Partial cooking of grain with intact husk to impart desirable hardness of kernel is termed as parboiling. Polish obtained from parboiled paddy in automatic rice mills is called PRP. Chemical analysis revealed that the PRP contains $13 \% \mathrm{CP}$ and $3250 \mathrm{kcal} \mathrm{ME} / \mathrm{kg}$ which is very much comparable to the nutrient content of wheat and maize (Zablan et al., 1963; Scott et al., 1976; Shivaji et al., 1983 and Eshwaraiah et al., 1988). However, PRP contains phytate phosphorus (Padua and Juliano, 1974; Barber and Barber, 1980), which reduces the phosphorus and calcium availability responsible for depressed performance of poultry on PRP diet. PRP also contains some non-starch polysaccharides such as cellulose, xylose, arabinose and galactonic acid that are not easily digested by poultry. The anti-nutritional effect is manifested by poor growth accompanied by depressed nutrient utilization. Recently, nutritionists are trying to utilize the efficiency of fibrous diet using 
different additives including enzymes. Addition of exogenous phytase and carbohydrase has been reported to improve feed utilization in broiler on PRP based diet (Moshad, 2001). Phytase that used in poultry diet also helps in reducing environmental pollution (Kies et al., 2001). Therefore, the adverse effects of PRP could possibly be overcome by dietary supplementation of exogenous phytase. Very few researchers examined the effect of using PRP fortified with phytase in the diet of ducks. Therefore, the present study was aimed at examining the effect of PRP and RB based diet with or without phytase on the growth performance of ducklings.

\section{MATERIALS AND METHODS}

The experiment was carried out in a shed type, well ventilated open-sided house for a period of 28 days. Allocated floor space was $900 \mathrm{~cm}^{2}$ per duckling. The whole wire meshed floor area was divided into a total of 12 uniform pens made of bamboo and wire net. A total of 48 as hatched individually wing banded Jinding DOD were randomly allocated to four (4) different dietary treatment groups, which was replicated three (3) times each. The diets were prepared replacing grain(s) by RB or PRP at a level of $20 \%$ with or without enzyme. Ducklings were fed ad libitum throughout the experimental period on 4 different isonitrogenous and iso-caloric diets namely: $D_{1}$ (containing $20 \% \mathrm{RB}$ without phytase), $\mathrm{D}_{2}$ (containing $20 \% \mathrm{RB}+$ $1 \%$ phytase), $D_{3}$ (containing $20 \%$ PRP without phytase) and $\mathrm{D}_{4}$ (containing $20 \%$ PRP $+1 \%$ phytase). The nutrient levels of the four diets were adjusted in accordance with the feeding standard recommended by NRC (1994). The test diets were formulated using locally available feed ingredients including RB, PRP, maize, soybean meal, protein concentrate (Jasoprot), L-lysine, DL-methionine, dicalcium phosphate, vitamin-mineral-amino acid premix, common salt and phytase enzyme (RenaPhytase-400; BASF, DSM, Renata Animal Health, Bangladesh). Feeds were supplied in mash form. One trough feeder and one round drinker were provided to each pen.

Table 1. Chemical composition of the experimental balanced ration

\begin{tabular}{|lc|}
\hline \multicolumn{1}{|c|}{ Nutrient } & Amount \\
\hline Metabolizable energy ( Kcal ME/kg) & 3000 \\
Crude protein (\%) & 22.0 \\
Crude Fiber (\%) & 6.0 \\
Calcium (\%) & 0.34 \\
Phosphorus (\%) & 0.65 \\
Lysine (\%) & 1.14 \\
Methionine (\%) & 0.36 \\
\hline
\end{tabular}

During the whole experimental period, all ducklings were exposed to a continuous lighting of 16 hours including day light and artificial light. Artificial lighting was reduced by 1 hour/week. Individual records were kept on initial and weekly live weight, weekly feed intake, feed conversion ratio (FCR) and survivability. All data either measured or calculated regarding growth, feed intake, FCR and feed cost were analysed by one-way ANOVA with the generalized linear model (GLM) using IBM SPSS Statistics version 19 (SPSS Inc., an IBM Company, Chicago, IL). In some cases where analyses revealed a significant treatment effect, the differences between mean values were evaluated using LSD (Least Significant Difference). A value of $\mathrm{P}<0.05$ was considered statistically significant, unless stated otherwise.

\section{RESULTS AND DISCUSSION}

\section{Live weight}

Live weight difference among ducklings on different dietary treatments was negligible $(p>0.05)$ at day old, but differences in live weight was marked $(p<0.01)$ with the increase of their age. PRP based diet fortified with phytase showed a definite superiority in increasing live weight gain of ducklings irrespective of age, over RB based diet $(p<0.01)$ (Table 2). Live weight of ducklings on PRP based diet without enzyme was increased by $7.15 \%$ than that on RB based diet. On the other hand, live weight on PRP based diet with enzyme increased by $7.36 \%$ than that on RB based diet. Superiority of PRP to RB irrespective of exogenous phytase, might be 
due to the removal of different toxins; saponin, pyridine, hemagluttinin and tannin during parboiling. Such type of possibility has been supported by Eshwaraiah et al., (1986). Islam (1994) reported that live weight decreased on diets containing increasing level of PRP. It decreased growth when levels of RP in the diet were above 40\% (Chaturvedi and Mukherjee, 1967). Kamal (1993) carried out an experiment with Khaki Campbell ducks under village condition and observed that supplementation of RP resulted in increased body weight gain in comparison with those receiving no RP. Increased live weight on RB and PRP based diet with enzyme was in agreement with Naher (2002), Moshad (2001) and Seskeviciene et al., (1999). Naher (2002) showed that addition of mixed enzyme increased meat yield of ducks.

\section{Feed intake}

Feed intake did not differ ( $p>0.05$ ) between PRP and RB based diets with or without exogenous phytase irrespective of age (Table 2), implying that the performance in terms of weight gain was influenced by diets with or without phytase without affecting feed intake. The result of adding coarse fibrous RB in the diets indicates that the volume of RB based diet may be an important factor to limit feed intake. Our results are in agreement with the findings of Steenfeld et al., (1998), who used cell wall degrading enzyme at the rate of 63 or $70 \mathrm{~g} / \mathrm{kg}$ wheat based diet and four different enzyme preparations (2 xylanase preparations and 2 mixed enzyme preparations) to more than $80 \mathrm{~g} / \mathrm{kg}$ of wheat based diet. In both cases, they observed that feed intake was not influenced by enzyme addition. Similar to the current findings, Richter et al., (1991) reported that enzyme supplementation has no impact on extra feed intake. However, Naher (2002) showed that addition of phytase and carbohydrase in the ration of ducks increased feed intake. In contrast to the present findings, Islam (1994) reported that feed intake increased with increasing PRP levels from 5.00 to $31.50 \%$ but decreased at $40.95 \%$ dietary PRP.

Table 2.The live weight, feed intake, feed conversion ratio and feed cost of ducklings on rice bran and parboiled rice polish based diets with or without enzyme at different ages

\begin{tabular}{|c|c|c|c|c|c|c|}
\hline \multirow[t]{2}{*}{ Parameter } & \multirow{2}{*}{$\begin{array}{l}\text { Age } \\
\text { (days) }\end{array}$} & \multicolumn{2}{|l|}{ RB (20\%) } & \multicolumn{2}{|c|}{ PRP (20\%) } & \multirow{2}{*}{$\begin{array}{l}\text { SED and } \\
\text { Significance }^{+}\end{array}$} \\
\hline & & $\begin{array}{l}\text { Phytase } \\
\text { (0g/kg) }\end{array}$ & $\begin{array}{l}\text { Phytase } \\
(10 \mathrm{~g} / \mathrm{kg})\end{array}$ & $\begin{array}{l}\text { Phytase } \\
\text { (0g/kg) }\end{array}$ & $\begin{array}{l}\text { Phytase } \\
(10 \mathrm{~g} / \mathrm{kg})\end{array}$ & \\
\hline \multirow[t]{5}{*}{ Live weight } & 0 & 49.67 & 50.33 & 51.67 & 49.33 & $1.130^{\mathrm{NS}}$ \\
\hline & 7 & $129.67^{d}$ & $136.00^{c}$ & $140.00^{b}$ & $147.00^{\mathrm{a}}$ & $2.060^{* *}$ \\
\hline & 14 & $231.33^{d}$ & $242.33^{c}$ & $248.67^{b}$ & $261.67^{a}$ & $2.940^{* *}$ \\
\hline & 21 & $422.33^{d}$ & $440.00^{c}$ & $448.33^{b}$ & $465.00^{a}$ & $3.590^{\star *}$ \\
\hline & 28 & $508.00^{d}$ & $530.00^{c}$ & $544.33^{b}$ & $569.00^{\mathrm{a}}$ & $4.460^{* *}$ \\
\hline \multirow[t]{4}{*}{ Feed intake } & 7 & 127.67 & 124.33 & 127.00 & 126.00 & $2.590^{\mathrm{NS}}$ \\
\hline & 14 & 210.33 & 210.67 & 211.00 & 210.33 & $2.660^{\mathrm{NS}}$ \\
\hline & 21 & 311.00 & 311.67 & 311.00 & 310.00 & $1.260^{N S}$ \\
\hline & 28 & 387.67 & 389.33 & 390.33 & 389.00 & $2.980^{\mathrm{NS}}$ \\
\hline \multirow[t]{4}{*}{ Feed conversion ratio } & 7 & $1.60^{a}$ & $1.45^{b}$ & $1.44^{b}$ & $1.29^{c}$ & $0.030^{* *}$ \\
\hline & 14 & $2.07^{a}$ & $1.98^{b}$ & $1.94^{b}$ & $1.82^{\mathrm{c}}$ & $0.030^{* *}$ \\
\hline & 21 & $1.64^{a}$ & $1.58^{b}$ & $1.56^{\mathrm{bc}}$ & $1.53^{c}$ & $0.030^{* *}$ \\
\hline & 28 & $4.55^{a}$ & $4.33^{b}$ & $4.07^{c}$ & $3.75^{d}$ & $0.080^{\star *}$ \\
\hline \multirow[t]{4}{*}{ Feed cost } & 7 & $2.55^{d}$ & $2.85^{b}$ & $2.66^{c}$ & $3.02^{a}$ & $0.060^{\star *}$ \\
\hline & 14 & $4.21^{b}$ & $4.84^{a}$ & $4.43^{\mathrm{ab}}$ & $4.72^{\mathrm{ab}}$ & $0.340^{N S}$ \\
\hline & 21 & $6.22^{d}$ & $7.16^{b}$ & $6.52^{\mathrm{c}}$ & $7.45^{\mathrm{a}}$ & $0.030^{* *}$ \\
\hline & 28 & $7.75^{\mathrm{d}}$ & $8.95^{b}$ & $8.20^{c}$ & $9.33^{a}$ & $0.070^{\star *}$ \\
\hline
\end{tabular}

${ }^{+} \mathrm{NS}, \mathrm{p}>0.05 ;{ }^{* *}, \mathrm{p}<0.01 ; \mathrm{RB}=$ rice bran; PRP = parboiled rice polish; SED = standard error difference.

\section{Feed Conversion Ratio}

FCR was higher in RB based diet than that on PRP based diet. FCR on PRP based diet without enzyme was improved by $10.55 \%$ than that on RB based diet. FCR on PRP based diet with enzyme was improved by $13.39 \%$ than that on RB based diet. The recorded lower FCR on PRP based diets with or without enzyme than that on RB based diets coincided with the findings of Moshad (2001), who reported improved feed conversion on PRP based diet with the addition of enzyme. Phytase that are used in poultry diet also helps in reducing environmental pollution (Kies et al., 2001). Phytin phosphorus is located in globoides in the aleurone 
protein bodies as potassium, magnesium salts. Its phosphate group can readily form complex with calcium, zinc, iron, protein and starch. Phytase can liberate (a proportion of) these compounds, thereby increasing the energy and protein value of the diet (Kies et al., 2001).

\section{Feed cost}

Feed cost on PRP based diet without enzyme was increased by $5.8 \%$ than that on RB based diet. Feed cost on PRP based diet with enzyme was increased by $4.25 \%$ than that on RB based diet. Higher feed cost on PRP based diets with enzyme supplementation is not supported by the findings of Farrell et al., (1993). The increasing performance on PRP diet in terms of live weight and feed conversion has been counteracted by remarkable decrease in feed cost on RB diet. The findings of the present study coincided with the results reported by Mikulshi et al., (1999), who replaced all wheat, two-third maize by triticale and barley supplemented with enzyme preparation (contained beta-glucanase, cellulase, protease and amylase) in their study. They showed that enzyme supplementation decreased the relative cost of feeds by $4-12 \%$ compared with the wheat-maize based control diet. It has also been stated that multi-enzyme supplementation to commercial broiler diet decreased feed cost by 8.81 to $9.73 \%$ for production of $1 \mathrm{~kg}$ broiler meat (Augelovicova and Michalik, 1997).

\section{Behaviour of ducklings}

Table 3. The behaviour; Proportionate time spent on feeding ( $F d)$, drinking (Dk), standing (St), and resting (Rt) of broilers fed on rice bran (RB) and parboiled rice polish (PRP) based diets

\begin{tabular}{|l|l|l|l|l|c|}
\hline \multirow{2}{*}{ Parameter } & \multicolumn{2}{|c|}{ RB (200g/kg) } & \multicolumn{2}{c|}{ PRP (200g/kg) } & \multirow{2}{*}{$\begin{array}{c}\text { SED and } \\
\text { significance }\end{array}$} \\
\cline { 2 - 5 } & $\begin{array}{l}\text { Phytase } \\
\text { (0g/kg) }\end{array}$ & $\begin{array}{l}\text { Phytase } \\
(\mathbf{1 0 g} / \mathbf{k g})\end{array}$ & $\begin{array}{l}\text { Phytase } \\
\text { (0g/kg) }\end{array}$ & $\begin{array}{l}\text { Phytase } \\
(\mathbf{1 0 g} / \mathbf{k g})\end{array}$ & \\
\hline Fd. & 16.55 & 17.33 & 17.67 & 18.00 & $1.620^{\mathrm{NS}}$ \\
Dk. & 14.67 & 14.83 & 15.17 & 14.50 & $1.170^{\mathrm{NS}}$ \\
St. & $47.50^{\mathrm{a}}$ & $47.33^{\mathrm{b}}$ & $40.33^{\mathrm{a}}$ & $40.00^{\mathrm{b}}$ & $2.600^{\star *}$ \\
Rt. & $20.00^{\mathrm{b}}$ & $20.50^{\mathrm{b}}$ & $26.50^{\mathrm{a}}$ & $28.83^{\mathrm{a}}$ & $2.200^{\star *}$ \\
\hline
\end{tabular}

$+\mathrm{NS}, \mathrm{p}>0.05,{ }^{* *}, p<0.01 ;$ All SEDs are against 3 error degrees of freedom

Regardless of phytase supplementation, proportionate time spent on feed intake was similar between RB and PRP based diets (Table 3). It appears that time spent on drinking seemed to be a simple function of feed intake. The birds having higher feed intake perhaps spent similar time in standing. Ducklings on PRP based diets with or without phytase took more rest than that on RB based diets with or without exogenous phytase. Taking more time for standing and resting indicates better feed conversion efficiency. The ducklings took more time for standing during feeding on RB based diet with or without enzyme than that on PRP based diets with or without enzyme. The reason behind this occurrence might be due to the increased volume of RB in the diets. Due to increased volume of RB in diets RB with or without enzyme, the birds took more time in feeding. As a result, birds had to stand more time for feeding. The behavioural pattern, irrespective of feeding, drinking, standing, and resting suggests that the behavioural component, especially time spent in resting and consequent feed conversion showed a significant positive relation. Appreciable increase in feed conversion efficiency obtained against higher resting time implies that time spent in activity incurs remarkable need of energy in feeding resulted efficient feed utilization. But the current information for such an occurrence could not be compared for the paucity of the published information at the present time. 


\section{CONCLUSION}

Based on the findings of the current study, it may be concluded that the inclusion of costlier PRP in the diet of ducklings resulted in higher growth rate and better feed efficiency as compared to that of cheaper RB. Supplementation of enzyme accelerated feed utilization as indicated by the increased performances of ducklings on diet with enzymes. Therefore, it is suggested to use phytase-fortified PRP based diet for feeding ducks. Augmentation of production performance seems to be a better option for the duck producers than the reduction of feed cost.

\section{REFERENCES}

1. Asian Livestock, 1978. FAO. Regional Animal Production and Health Commission for Asia and the Pacific (APHCA). 10: 6.

2. Augelovicam M and I Michalik, 1997. A test of enzymatic preparation in relation to performance and commercial utilization of feeds in broiler chickens. 42: 175-180.

3. Banerjee G C, 1992. Classification and composition table for poultry feeds. $3^{\text {rd }}$ edition, $105-108$.

4. Barber S K and P K Barber, 1980. Utilization of rice bran by broiler and layer chicken. Poultry Science, 59: 1012-1017.

5. Chaturvedi, D. K. and Mukherjee, R. 1967. Studies on cereal free rations based on rice polishing and groundnut cake for growing chicks. Indian Journal of Poultry Science, 2: 36-51.

6. Eshwaraiah; Reddy C V and V P Rao, 1988. Effect of autocalaving and solid substrate fermentation of raw, deoiled and parboiled rice polishing in broiler diets. Indian Journal of Animal Science, 58: 377 381.

7. FAO, 2009. Food and Agriculture Organization. Year Book, 57: 211.

8. Houston D F and G O Kohler, 1970. Nutritional of rice. National Academy of Science. Washington. D.C.

9. Islam NM, 1994. Parboiled rice polish as a dietary substitute of wheat on growth performance and meat yield of broilers. Ph.D. Thesis. Department of Poultry Science, Bangladesh Agricultural University, Mymensingh, Bangladesh.

10. JulianoBO (editor), 1985. Rice Chemistry and technology $2^{\text {nd }}$ edition American Association of cereal chemists Inc. St. Paul, Minnesota, U.S.A.

11. Kamal MM, 1993. Study on the effect of supplementation of rice polish on the performance of Khaki Campbell Duck under village condition. M.Sc. Thesis, Department of Animal Nutrition, Bangladesh Agricultural University, Mymensingh, Bangladesh.

12. Kanaya $\mathrm{K}$, Yasumoto $\mathrm{K}$ and $\mathrm{H}$ Mitsuda, 1976. Pepsin inhibition by phytate contained in rice bran, In: B. O. Juliano (editor) 1985. Rice chemistry and technology $2^{\text {nd }}$ edition. American Association of Cereal Chemists. Inc. St. Paul. Minnesota, USA.

13. Kies A K,Vanhemert K A F and W C Saur, 2001. Effect of phytase on protein and amino acid acid digestibility and energy utilization. World's Poultry Science Journal, 57: 109-124

14. McDonald P, Edwards R A and J F D Greenhulgh, 1987. Nutritive value of food for poultry. Animal Nutrition $4^{\text {th }}$ edition, Longman Group Ltd. U.K.

15. Mikulski, D.; Jankowski, J.; Farugh, A. and Zeid, A. E. 1999. Effect of feeding enzyme-supplemented triticale-bareley diets on broiler chicken. Egyptian poultry Science Journal, 19: 607-618.

16. Morrison F B, 1957. Feed and feeding $2^{\text {nd }}$ edition. Marrison Publishing Co. Ithaca, New York.

17. Moshad M A, 2001. Use of phytase and carbohydrase enzyme for better utilization of parboiled rice polish based diet in Broilers. M.S. Thesis, Department of Poultry Science, Bangladesh Agricultural University, Mymensingh.

18. Naher B, 2002. Utilization of parboiled rice polish based diet with supplementation of carbohydrase and phytase in growing ducklings. M. S. thesis, Department of Poultry Science, Bangladesh Agricultural University, Mymensingh.

19. Pauda I B and C H Julinao, 1974. Phytase on the utilization of chicks. Journal of nutrition, 104: 2032038. 
20. Richter G, Lemsef A, Cyriaci G and J Schwartze, 1991. Evaluation of microbial phytase in broiler feeding. Poultry Abstracts, 1993. 19.

21. Scott M L,Nesheim M C and R J Young, 1976. Nutrition of the chicken, $2^{\text {nd }}$ edition. M. L. Scott Associates. Ithaca, New York.

22. Shaheen A B and Shirbeeny, 1975. Effect of parboiling of rice on the rate of lipid hydrolsis and deterioration of rice bran. Cereal chemistry, 52: 1-8.

23. Shivaj S, Zambade S S,Jagmohan S and J S Ichnopnani, 1983. Nutritive value of raw, parboiled, Stabilized and deoiled rice bran for growing chicks. Journal of Food and Agriculture, 34: 743-788.

24. Steenfeld S,Mulleriz A and J F Jenson, 1998. Enzyme supplementation of Wheat based diets for broilers. Effect on growth performance and intestinal viscosity. Animal Feed Science and Technology, 75: 27-43.

25. Thompson S A and CW Weber, 1981. Effect of dietary fibre sources on tissue mineral level in chicks. Poultry Science, 60: 840-845.

26. Warren B F and D J Farrell, 1990. The nutritive value of full-fat and defatted Austrialian rice bran. I. Chemical Composition. II Growth studies with chicken, rats and pigs. Animal Feed Science and Technology, 27: 229-246.

27. Zablan T A, Griffith A M, Nesheim M C, Young R J and ML Scott, 1963. Matabolizable energy of some oil seed meals and unusual feedstuffs. Poultry Science, 42: 619-625. 